\section{É Possível Usar a Hidrocortisona no Tratamento da Cefaléia após Raquianestesia?}

\section{Prezada Editora,}

A cefaléia postural após punção de dura-máter (CPPD) é complicação esperada, porém rara nos dias atuais em virtude do menor calibre das agulhas em relação às utilizadas no passado ${ }^{1}$. A incidência atual dessa cefaléia está estimada entre $2,4 \%$ com agulha Whitacre $25 \mathrm{G}$ e $0,4 \% \mathrm{com}$ a mesma agulha calibre $27 \mathrm{G}^{2}$. Quando a mesma agulha é reprocessada a incidência de CPPD aumenta ${ }^{2}$.

A fisiopatologia que esclarece o quadro doloroso não está completamente definida ${ }^{1}$, porém a explicação mais aceita não difere muito daquela postulada por Bier, com base na perda de líquor (LCR). A diminuição da pressão no LCR com tração das estruturas dolorosas quando o paciente assume a posição ortostática parece ser o principal responsável pela cefaléia ${ }^{1,3,4}$. A pressão liquórica normal na posição horizontal varia de 5 a $15 \mathrm{~cm} \mathrm{H}_{2} \mathrm{O}{ }^{1,3}$, porém após a punção dural essa pressão fica reduzida a valores inferiores a $4 \mathrm{~cm}$ $\mathrm{H}_{2} \mathrm{O}{ }^{3}$. A vasodilatação reflexa na tentativa de corrigir a diminuição da pressão intracraniana é outro fator que contribui para o aparecimento do quadro ${ }^{1,3}$.

A incidência de CPPD diminui com o aumento da idade e com o uso de agulhas de pequeno diâmetro ${ }^{1,3,4}$. Quando as diferenças de idade são levadas em consideração nos estudos, não parece haver diferença na incidência entre os sexos ${ }^{4}$. A inserção de agulhas com bisel alinhado paralelo ao eixo longitudinal das meninges diminui a incidência de cefaléia, apesar de se saber que as fibras colágenas da dura-máter são dispostas de modo aleatório ${ }^{1,3,4}$.

O tratamento deve ser individualizado e depende da intensidade da dor, podendo ser clínico ou através do tampão sangüíneo peridural. $O$ tratamento clínico consiste em repouso para alívio dos sintomas, hidratação venosa ${ }^{4-7} \mathrm{e}$ uso de algumas medicações, como: cafeína ${ }^{1,3,4,6,7}$, sumatriptan ${ }^{1,3}$, tiaprida ${ }^{3,6}$ e os analgésicos antiinflamatórios nãohormonais $1,3,4,6,7$.

Foi postulado que a CPPD poderia ocorrer em um grupo específico de pacientes que seriam mais propensos ao estresse fisiológico e mostrariam marcado hipercortisolismo com uma resposta diferente ao trauma e a outros tipos de estresse ${ }^{8,9}$. O aumento do cortisol exerce efeito negativo na secreção do hormônio adrenocorticotrófico (ACTH) e anula os seus efeitos benéficos ${ }^{9}$.

O ACTH tem sido utilizado nos casos de falha do tampão e nos pacientes refratários às medidas conservadoras ${ }^{3,7}$. Ele possui uma efetividade de $70 \%{ }^{7-10}$ e pode ser usado por via venosa ou intramuscular ${ }^{8}$. Após administração seu efeito de pico ocorre entre seis e oito horas ${ }^{11}$.

Os mecanismos de ação propostos para o ACTH incluem: aumento na produção de líquor e das beta-endorfinas ${ }^{9,10,12}$, e liberação de esteróides pela supra-renal ${ }^{9,11,12}$. O ACTH e as beta-endorfinas provêm da mesma molécula precursora, proopiomelanocortina, e quando o ACTH é clivado enzimaticamente gera metabólitos que servem de suporte na produção das beta-endorfinas ${ }^{9}$. O efeito antiinflamatório do ACTH pode ser decorrente da liberação do cortisol e da corticosterona pela supra-renal ${ }^{9}$.

Levando-se em consideração que o ACTH poderia agir por meio da liberação de glicocorticóides endógenos e também pela inacessibilidade a essa droga em alguns países a literatura passou a relatar o uso da hidrocortisona em substituição ao ACTH para o tratamento da CPPD com relativo sucesso ${ }^{6,7,12,13}$. A hidrocortisona possui ação antiinflamatória e pode agir no nível da bomba de $\mathrm{Na} / \mathrm{K}$ ATPase com aumento na produção do LCR ${ }^{6,7,13}$. Por outro lado, vale lembrar que o quadro doloroso pode ser resolvido de maneira espontânea e independentemente do uso da hidrocortisona e isso nos leva a pensar em seu uso com ressalvas e até mesmo a duvidar da sua eficácia analgésica. Mais estudos com maior qualidade metodológica são necessários para definir o real papel desse fármaco no tratamento da CPPD assim como a dose ideal para a prática cotidiana.

Atenciosamente,

Fabiano Timbó Barbosa, TSA

Rafael Martins da Cunha

\section{Is it Possible to Use Hydrocortisone to Treat Post-Spinal Anesthesia Headache?}

To the Editor,

Postural postdural puncture headache (PPDPH) is a known complication, but rare nowadays due to the reduced caliber of the needles compared to the ones used in the past ${ }^{1}$. The current incidence of this type of headache is approximately $2.4 \%$ with a $25 \mathrm{G}$ Whitacre needle and $0.4 \%$ with the $27 \mathrm{G}$ needle of the same brand ${ }^{2}$. The incidence of PPDPH increases when the same needle is reprocessed ${ }^{2}$.

The physiopathology of this painful syndrome is not completely elucidated ${ }^{1}$, but the most accepted cause does not differ much from that postulated by Bier, based on the loss of cerebrospinal fluid (CF). The fall in the pressure of the $\mathrm{CF}$ with contraction of painful structures when the patient is erect seems to be the main reason for the headache ${ }^{1,3,4}$. The normal pressure of the spinal fluid in the horizontal position is between 5 an $15 \mathrm{~cm} \mathrm{H}_{2} \mathrm{O}{ }^{1,3}$, but after dural puncture, it might fall below $4 \mathrm{~cm} \mathrm{H}_{2} \mathrm{O}^{3}$. Reflex vasodilation in an attempt to correct the reduced intracranial pressure also contributes for the development of this symptom ${ }^{1,3}$. 
The incidence of PPDPH decreases with age and with the use of small caliber needles ${ }^{1,3,4}$. When the studies consider age differences, the incidence does not seem to be different between genders ${ }^{4}$. The introduction of the needle with the bevel parallel to the longitudinal axis of the meninges reduces the incidence of headache, although it is known that collagen fibers in the dura mater are randomly distributed ${ }^{1,3,4}$. The treatment should be individualized, dependent on the severity of pain, and it can be clinical or using the epidural blood patch. Clinical treatment includes bed rest to relieve the symptoms, intravenous hydration ${ }^{4-7}$, and the use of a few drugs, such as: caffeine ${ }^{1,3,4,6,7}$, sumatriptan ${ }^{1,3}$, tiapride ${ }^{3,6}$, and non-steroidal anti-inflammatory drugs ${ }^{1,3,4,6,7}$.

It has been postulated that PPDPH could affect a specific group of patients that would be more prone to physiological stress, and develop accentuated hypercostisolism, with a different response to trauma and other types of stress ${ }^{8,9}$. The increase in cortisol has a negative effect in the secretion of the adrenocorticotrophic (ACTH) hormone and counteracts its beneficial effects ${ }^{9}$.

ACTH has been used in cases of failure of the blood patch and in patients refractory to conservative measures ${ }^{3,7}$. It has a $70 \%{ }^{7-10}$ efficacy rate and can be administered IV or IM ${ }^{8}$. After administration, the peak concentration is reached in 6 to 8 hours ${ }^{11}$.

The mechanisms of action proposed for ACTH include: increased production of spinal fluid and beta-endorphins $9,10,12$ and release of steroids by the adrenal glands ${ }^{9,11,12}$. ACTH and beta-endorphins originate from the same precursor molecule, a proopiomelanocortin, and when ACTH is cleaved enzymatically, it generates metabolites that are used in the production of beta-endorphins ${ }^{9}$. The anti-inflammatory effects of ACTH could be secondary to the release of cortisol and corticosterone by the adrenal glands ${ }^{9}$.

Considering that the actions of ACTH could be through the release of endogenous glucocorticoids and the fact that this drug is not readily obtainable in some countries, researchers started to report the use of hydrocortisone in place of ACTH in the treatment of PPDPH with success ${ }^{6,7,12,13}$. Hydrocortisone has an anti-inflammatory action, and it can act at the level of the $\mathrm{Na} / \mathrm{K}$ ATPase pump, increasing the production of CF. On the other hand, one should remember that the painful syndrome may resolve spontaneously and independent of the use or not of hydrocortisone, and that this indicates it should be used carefully and even leads one to question its analgesic efficacy. Further studies with better methodological quality are needed to define the true role of this drug in the treatment of PPDPH, as well as the ideal dose.

Sincerely,

Fabiano Timbó Barbosa, TSA

Rafael Martins da Cunha

\section{REFERÊNCIAS - REFERENCES}

01. Turnbull DK, Shepherd DB - Post-dural puncture headache: pathogenesis, prevention and tretment. Br J Anaesth, 2003; 91:718-729.

02. Mathias RS, Torres MLA - Analgesia e Anesthesia em Obstetrícia, em: Yamashita AM, Takaoka F, Auler Junior JOC et al. Anestesiologia. 5aㅡ Ed. São Paulo, Atheneu, 2001;679-730.

03. Cavicchio A, Imbelloni LE - Cefaléia Pós-Punção, em: Imbelloni LF - Tratado de Anestesia Raquidiana. Curitiba, Posigraf, 2001;178-191.

04. Bernards CM - Anestesia Epidural e Subdural, em: Barash PG Cullen BF, Soetlting RK - Anestesia Clínica. 4를 Ed. São Paulo, Manole, 2004;689-714.

05. Stanicia S - Bloqueio Subaracnóideo e Epidural, em: Yamashita AM, Takaoka F, Auler Junior JOC et al. - Anestesiologia. $5^{\text {a }}$ Ed. São Paulo, Atheneu, 2001;597-612.

06. Carvalo WSR, Marzochi LML, Passo IP - Uso da hidrocortisona no tratamento da cefaléia após punção da dura-máter. São Paulo MJ, 2006;124(Suppl):100.

07. Neves JFNP, Vieira VLR, Saldanha RM et al. - Uso da hidrocortisona no tratamento e na prevenção da cefaléia póspunção de dura-máter. Relato de casos. Rev Bras Anestesiol, 2005;55:343-349.

08. van den Berg AA, Nguyen L, von-Maszewsk $M$ et al. Unexplained fitting in patients with post-dural puncture headache. Risk of iatrogenic pneumocephalus with air rationalizes use of loss of resistance to saline. Brit J Anaesth, 2003; 90:810-811.

09. Kshatri AM \& Foster PA - Adrenocorticotropic hormone infusion as a novel treatment for postdural puncture headache. Reg Anesth, 1997;22:432-434.

10. Foster $\mathrm{P}-\mathrm{ACTH}$ treatment for post-lumbar puncture headache. Brit J Anaesth, 1994;73:429.

11. Laviola S, Kirvela M, Spoto M et al. - Pneumocephalus with intense headache and unilateral pupillary dilatation alter accidental dural puncture during epidural anesthesia for cesarean section. Anesth Analg, 1999;88:582-583.

12. Castellana FB, Laranjeira A, Schiavuzzo FA et al. - Hidrocortisona como tratamento para cefaléia pós-punção de duramáter: série de casos. São Paulo MJ, 2006;124(Suppl):70.

13. Moral Turiel M, Rodrigues Simon MO, Sahagun de la Lastra J et al. - Tratamiento de la cefalea postpunción dural con hidrocortisona intravenosa. Rev Esp Anestesiol Reanim, 2002; 49:101-104. 